\title{
Turning organic waste into organic fertilizers in the village Namo Bintang Deli Serdang regency
}

\author{
Miswar Budi Mulya ${ }^{1 *}$, Ternala Alexander Barus ${ }^{1}$, Arlen H.J ${ }^{2}$, Nursal $^{3}$, Kiki Nurtjahya ${ }^{4}$ \\ ${ }^{1}$ Faculty of Mathematics and Natural Science, Universitas Sumatera Utara, Medan, Indonesia \\ *Email: miswarbm_ikl@yahoo.com
}

\begin{abstract}
Community service activities titled Transforming Organic Waste into Organic Fertilizer in Namo Bintang Village in May - November 2019. This activity aims to convert organic waste into organic fertilizer that has economic value, and does not endanger the environment. The method used is counseling, lectures and training as well as monitoring and evaluation with the community directly to the field.

Organic waste processing is carried out in several places in the village of Namo Bintang with the approval of the village head and the community. The activities are carried out by means of counseling and lectures, explanations of theories and integrated waste management techniques that are followed by the farmers and scavenger groups of Namo Bintang Village. The community listens to the material delivered by the community service team.

The training was conducted by community groups of farmers and scavengers in Namo Bintang Village. Peasant and scavenger community groups are trained by the community service team. All carried out this activity by proactively conducting training to get results in the form of fertilizer from organic waste. The results were reviewed by community groups after 10 days of training to see organic fertilizer. The equipment for utilizing organic waste is also very simple so that community groups can make it themselves.

And finally the monitoring and evaluation of the success of monitoring the work in the field will be carried out by going directly to the field together, monitoring by visiting to find out whether the community can do it themselves, besides that the relationship will be carried out by telephone to overcome the problems that arise.

In general, community service activities have been successfully carried out and seen a good cooperative relationship between the Higher Education, especially the Implementation Team, government officials and the community in Namo Bintang Village. The village community realizes the importance of saving the environment from increasing their life expectancy because they can make their own fertilizer / compost.

Keyword: Change, Organic Trash, Organic Fertilizer, Namo Bintang Village
\end{abstract}

\begin{abstract}
Abstrak
Kegiatan pengabdian pada masyarakat dengan judul Mengubah Sampah Organik menjadi Pupuk organik di Desa Namo Bintang pada bulan Mei - November 2019. Kegiatan ini bertujuan mengubah sampah organik menjadi pupuk organik yang memiliki nilai ekonomis, dan tidak membahayakan bagi lingkungan hidup. Metode yang digunakan adalah penyuluhan, ceramah dan pelatihan serta monitoring dan evaluasi bersama masyarakat langsung ke lapangan.

Pengolahan sampah organik dilakukan di beberapa tempat di desa Namo Bintang dengan persetujuan Kepala desa dan masyarakatnya. Pelaksanaan kegiatan dilakukan dengan cara penyuluhan dan ceramah, penjelasan teori dan teknik pengolahan sampah terpadu yang diikuti kelompok masyarakat Petani dan Pemulung Desa Namo Bintang. Masyarakat tersebut mendengarkan materi yang disampaikan oleh tim pengabdian masyarakat.
\end{abstract}

Pelatihan dilakukan oleh kelompok masyarakat petani dan Pemulung di Desa Namo Bintang. Kelompok masyarakat petani dan pemulung dilatih oleh tim pengabdian masyarakat. Semua melakukan kegiatan ini dengan proaktif melakukan pelatihan untuk mendapatkan hasil berupa pupuk dari sampah organik. Hasil dilihat kembali oleh kelompok masyarakat setelah 10 hari pelatihan untuk melihat pupuk organik. Peralatan untuk pemanfaatan sampah organik juga sangat sederhana sehingga kelompok masyarakat bisa membuatnya sendiri.

Dan terakhir monitoring dan evaluasi keberhasilan pemantauan pekerjaan di lapangan akan dilakukan dengan turun langsung ke lapangan secara bersama-sama, pemantauan dengan kunjungan untuk mengetahui apakah masyarakat sudah bisa melakukan sendiri, Selain itu hubungan akan dilakukan lewat telepon untuk mengatasi masalah-masalah yang timbul.

Secara umum kegiatan pengabdian pada masyarakat ini berhasil dilakukan dan terlihat adanya hubungan kerjasama yang baik antara Perguruan Tinggi khususnya Tim Pelaksana, aparat pemerintahan dan 
masyarakat di Desa Namo Bintang. Masyarakat desa menyadari pentingnya menyelamatkan lingkungan dari sekaligus meningkatkan tarap hidup karena sudah dapat membuat pupuk /kompos sendiri.

Kata Kunci: Mengubah, Sampah Organik, Pupuk Organik, Desa Namo Bintang

\section{PENDAhuluan}

Desa Namo Bintang adalah salah satu desa yang terletak di kecamatan Pancur Batu, Kabupaten Deli Serdang. Di desa Namo Bintang juga terdapat Tempat Pembuangan Akhir Sampah (TPA) Kotamadya Medan atau lazimnya disingkat dengan TPA Kecamatan Pancur Batu Kabupaten Deli Serdang, terletak di sebelah Utara desa Namo Bintang dan mempunyai luas areal sekitar 25 hektare. Jarak dari pemukiman ke areal TPA ini sekitar 1,5 km dan terletak di pinggir jalan arah jalan besar Pancur Batu. Sedangkan jarak dari Kotamadya Medan ke TPA ini berkisar 17 km.

\begin{tabular}{llc}
\hline No & \multicolumn{1}{c}{ Mata pencaharian } & Jumlah (KK) \\
\hline 1. & PNS/ABRI/TNI/POLRI & 65 \\
2. & Pegawai Swasta & 143 \\
3. & Pemungut Barang Bekas/Pemulung & 241 \\
4. & Petani & $\mathbf{2 5 6}$ \\
5. & Pedagang & 67 \\
6. & Jasa & 84 \\
7. & Pensiunan & 62 \\
8. & Buruh & 87 \\
& Jumlah & 1005 \\
\hline
\end{tabular}

Tabel 1.1. Komposisi Penduduk Menurut Mata Pencaharian

Masyarakat Desa Namo Bintang banyak membuang sampah di sungai dan dibakar. Sampah sering kali menumpuk di pinggir jalan dan sungai, sehingga menganggu lingkungan. Selain itu tercecernya sampah ke area sawah karena terbawa oleh aliran sungai. Sampah tersebut bertumpuk sehingga aliran air selokan atau sungai tersumbat. Ketika curah hujan tinggi dan berlangsung lama, akan mengakibatkan banjir.

Berdasarkan kondisi inilah maka mitra berupa Kelompok Petani desa Namo Bintang bekerja sama dengan tim pengabdian bekerjasama memanfaatan sampah organik menjadi pupuk organik. Dengan adanya pemanfaatan sampah organik ini, masyarakat Desa Namo Bintang mendapat pengetahuan dan pelatihan pemanfatan sampah organik menjadi pupuk organik untuk menambah ekonomi keluarga, sekaligus mengurangi pencemaran lingkungan.

Masyarakat Desa Namo Bintang banyak membuang sampah di sungai dan dibakar. Sampah sering kali menumpuk di pinggir jalan dan sungai, sehingga menganggu lingkungan. Selain itu tercecernya sampah ke area sawah karena terbawa oleh aliran sungai. Sampah tersebut bertumpuk sehingga aliran air selokan atau sungai tersumbat. Ketika curah hujan tinggi dan berlangsung lama, akan mengakibatkan banjir.

Berdasarkan kondisi inilah maka mitra berupa Kelompok Petani desa Namo Bintang bekerja sama dengan tim pengabdian bekerjasama memanfaatan sampah organik menjadi pupuk organik. Dengan adanya pemanfaatan sampah organik ini, masyarakat Desa Namo Bintang mendapat pengetahuan dan pelatihan pemanfatan sampah organik menjadi pupuk organik untuk menambah ekonomi keluarga, sekaligus mengurangi pencemaran lingkungan. 


\section{METODE PELAKSANAAN}

Metode yang digunakan dalam kegiatan ini dengan cara penyuluhan dan ceramah, penjelasan teori dan teknik pemanfaatan sampah organik, yang diikuti kelompok masyarakat Petani di Desa Namo Bintang. Masyarakat tersebut mendengarkan materi yang disampaikan oleh tim pengabdian masyarakat.

Pelatihan dilakukan oleh kelompok masyarakat Petani di Desa Namo Bintang. Kelompok masyarakat dilatih oleh tim pengabdian masyarakat. Semua melakukan kegiatan ini dengan proaktif melakukan pelatihan untuk mendapatkan hasil berupa pupuk organik/kompos. Peralatan juga sangat sederhana sehingga kelompok masyarakat bisa membuatnya sendiri.

Monitoring dan evaluasi keberhasilan pemanfaatan sampah organik dan pemantauan pekerjaan di lapangan akan dilakukan dengan turun langsung ke lapangan secara bersama-sama, pemantauan dengan kunjungan untuk melihat apakah masyarakat sudah bisa membuat pupuk organik sendiri. Selain itu hubungan akan dilakukan lewat telepon untuk mengatasi masalahmasalah yang timbul.

Secara umum kegiatan pengabdian pada masyarakat ini berhasil dilakukan dan terlihat adanya hubungan kerjasama yang baik antara Perguruan Tinggi khususnya Tim Pelaksana, aparat pemerintahan dan masyarakat Petani di Desa Namo Bintang. Masyarakat Desa Namo Bintang menyadari pentingnya menyelamatkan lingkungan sekaligus meningkatkan tarap hidup karena sudah dapat membuat pupuk organik sendiri.

Keberhasilan dari kegiatan pengabdian pada masyarakat tidak lepas dari peran serta dan dukungan Aparat Desa seperti Kepala Desa Namo Bintang serta jajarannya, kelompok Petani untuk ikut serta dalam kegiatan ini.

\section{GAMBARAN MENGUBAH SAMPAH ORGANIK MENJADI PUPUK ORGANIK}

\section{A. PENYULUHAN}<smiles>C1=CCCC1</smiles>

PEMBUATAN PUPUK ORGANIK

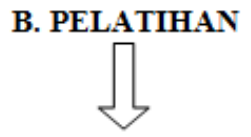

\section{PERSIAPAN ALAT DAN BAHAN}

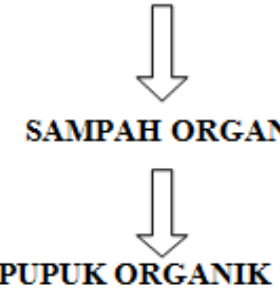

Gambar 2.1. Mengubah sampah organik menjadi popok organik

\section{HASIL DAN PEMBAHASAN}

Pelaksanaan kegiatan dilakukan dengan cara penyuluhan dan ceramah, penjelasan teori dan teknik pengolahan terpadu, yang diikuti kelompok masyarakat di Desa Namo Bintang Kabupaten Deli Serdang. Masyarakat desa mendengarkan materi yang disampaikan oleh tim pengabdian 
masyarakat. Materi yang disampaikan menyangkut tentang mengubah sampah organik menjadi kompos/pupuk organik. Diharapkan kelompok masyarakat dapat menekan biaya produksi rumah tangga karena sudah bisa mendapatkan dan memproduksi kompos/pupuk sendiri sesuai dengan kebutuhannya. Jadi kelompok masyarakat bisa menyelamatkan lingkungan dan meningkatkan taraf hidup keluarganya.

Pelatihan dilakukan oleh kelompok masyarakat didesa Namo Bintang dilatih oleh tim pengabdian masyarakat. Semua melakukan kegiatan ini dengan proaktif melakukan pelatihan untuk mendapatkan hasil berupa kompos/pupuk organik dari sampah organik. Hasil dilihat langsung untuk pemanfatan sampah anorganik menjadi pupuk oleh kelompok masyarakat setelah 21 hari pelatihan dapat dilihat hasilnya. Peralatan untuk pembuatan pemanfaatan sampah organik juga sangat sederhana sehingga kelompok masyarakat petani bisa membuatnya sendiri.

Kegiatan mengubah sampah organik sangat mendukung karena sampah sangat banyak di desa Namo Bintang tersebut, jadi masyarakat sangat mudah mengambilnya untuk bahan pembuatan kompos/pupuk organik. Alat yang digunakan untuk pembuatan kompos sangat sederhana sehingga kelompok masyarakat desa bisa membuatnya sendiri. Selain itu desa dapat diselamatkan lingkungannya dari sampah sekaligus meningkatkan taraf hidup karena sudah bisa membuat bahan kerajinan tangan dan kompos sendiri.

Pembuatan kompos/pupuk organik memerlukan waktu untuk menghasilkan produk, karena prosesnya harus didiamkan atau di fermentasikan selama beberapa hari. Jadi kelompok masyarakat harus punya teknis mengunanya dan pemanfaatannya.

\section{KESIMPULAN}

Dari kegiatan mengubah sampah organik menjadi pupuk organik di desa Namo Bintang Kabupaten Deli Serdang, dapat diambil kesimpulan sebagai berikut :

1. Mengubah sampah organik menjadi pupuk organik

2. Pemanfaatan sampah organik dapat memberikan nilai ekonomis dan ekologis.

3. Terdapat kerjasama yang baik antara USU dan masyarakat di desa Namo Bintang Kabupaten Deli Serdang.

\section{UCAPAN TERIMAKASIH}

Dalam kesempatan ini kami mengucapkan terima kasih kepada Non PNBP Tahun 2019 sebagai penyandang dana dan segenap pihak yang telah membantu dalam pelaksanaan Pengabdian Kepada Masyarakat ini. Harapan kami semoga program ini dapat berlanjut dalam usaha pengelolaan lingkungan dengan mengubah sampah organik menjadi pupuk organik/kompos.

\section{DAFTAR PUSTAKA}

Chalimah, S. Aminah A, Mahajoeno E. 2012. Produksi campuran pupuk organik dan pupuk hayati mikoriza (CMA) dari bahan gulma air dan kotoran ayam menuju infrastruktur hijau. Prosiding Semnas Greentec 3. UIN Malang.

Djaja, W. 2008. "Langkah Jitu Membuat Kompos Ternak dan Sampah”. Agomedia Pustaka, Jakarta

Glio, M. Tosin. 2015. "Pupuk Organik \& Pestisida Nabati No. 1 ala Tosin Glio". PT. Ago Media Pustaka. Jakarta.

Mandailing, M.M., M. S. Saeni, Said Rusli. 2001. Partisipasi Pedagang Dalam Program Kebersihan dan Pengelolaan Sampah Pasar (Kasus Di Kota Bogor).Tesis Program Pascasarjana IPB. Tidak diterbitkan. 
Mulyono, 2014.” Membuat Mol dan Kompos dari Sampah Rumah Tangga”. PT. AgoMedia Pustaka : Jakarta.

Peraturan Menteri Pertanian No. 70/Permentan/SR.140/20/2011. Pupuk Organik, Pupuk Hayati, dan Pembenah Tanah

Saraswati, Rasti. 2006. "Pupuk Organik dan Pupuk Hayati (ORGANIC FELTILIZER AND BIOFERTILIZER". Balai Besar Litbang Sumberdaya Lahan Pertanian. Badan Penelitian dan Pengembangan Pertanian (BPPP).

Virgota, A., S. E. Gumbira, A. Saefuddin. 2001. Kajian Simulasi Kelayakan Sistem Pemisahan Sampah Rumah Tangga pada Pengelolaan Sampah di Kotamadya Pekanbaru, Riau. Tesis Program Pascasarjana IPB. Tidak diterbitkan. 